\title{
Bodyweight Change and Carcass Yield Performance of Somali Goats Fed with Groundnut Pod Hulls and a Mixture of Wheat Branand Mustard Seed Cake
}

\author{
Tesfaye Worku $^{1^{*}}$ and Mengistu Urge ${ }^{2}$
}

\author{
${ }^{1}$ Department of Animal Sciences, College of Agriculture and Natural Resources, Wollega University, \\ P.O. Box: 395, Nekemete, Ethiopia. \\ ${ }^{2}$ School of Animal and Range Sciences, Haramaya University, P.O.Box: 138, Dire Dawa, Ethiopia
}

\begin{abstract}
The study was conducted at Kombolcha ATVET College, Eastern Ethiopia using 25 intact male yearling Somali goats weighing $18.4 \pm 1.5 \mathrm{~kg}$ at the start of the experiment. The objectives of the study was to examine the effects of urea treated groundnut pod hulls and supplementation of wheat bran and mustard seed cake mixture at a ratio of $3: 1$, respectively at different levels on body weight change and carcass yield performance of Somali goats. A completely randomized block design was employed and the experimental animals were grouped in five blocks of five goats each based on their initial BW. The goats within a block were randomly assigned to one of the five diets. Treatment feeds consisted feeding of sole untreated groundnut pod hulls (UGNPH) (T1) adlibtum, sole urea treated (UTGNPH) (T2) adlibtum, and supplementation of the UGNPH with the concentrate mixture at graded levels of $125 \mathrm{~g}$ (T3), $250 \mathrm{~g}$ (T4) and $375 \mathrm{~g} \mathrm{DM} / \mathrm{head} /$ day (T5). Daily DM intake of UGNPH was higher $(P<0.001)$ in T1 $(407.1 \mathrm{~g} / \mathrm{head} /$ day $)$ and T3 $(388.7 \mathrm{~g} / \mathrm{head} /$ day $)$ compared to T4 $(331.5 \mathrm{~g} / \mathrm{head}$ day) and T5 (272.1 g/head/day), whereas that of UTGNPH was higher $(P<0.001)$ for T2 $(471.1$ $\mathrm{g} /$ day/head) compared to all treatments. Total DM intake was higher $(P<0.001)$ in supplemented groups (T3, T4, and T5) compared to non-supplemented groups (T1and T2). Goats fed sole UGNPH (T1) and UTGNH (T2) lost BW at a rate of 31 and $6 \mathrm{~g}$ per day, respectively, whereas supplemented goats gained BW at a rate of 18.9(T3), 40.7(T4), and $53.3 \mathrm{~g}(\mathrm{~T} 5)$ per day. Goats supplemented with concentrate had higher $(P<0.001)$ weight of hot carcass and empty bodyweight (BW). Better dressing percentage was obtained $(P<0.01)$ in supplemented and UTGNPH group on empty and slaughter BW basis. The result of this experiment demonstrated that urea treatment increased intake of groundnut pod hulls and decreased body weight loss as compared to the UGNPH. We recommend supplementation with $375 \mathrm{~g} \mathrm{DM} /$ day/head of the concentrate mixture to UGNPH based diet for small scale goat fattening programs, since neither UGNPH nor UTGNPH provided sufficient nutrients for growing goats.
\end{abstract}

Article Information Article History:

Received :25-01-2014

Revised : 20-03-2014

Accepted : 26-03-2014

Keywords:

Carcass performance

Body weight change

Somali goat

Mustard seed cake

Wheat bran

Supplementation

Copyright@2014 STAR Journal. All Rights Reserved.

\section{INTRODUCTION}

Ethiopia is home to about 14 indigenous breeds or ecotypes of goats that are distributed across all agroecological zones and ruminant livestock production systems (FARM-Africa, 1996; FAO, 1999). Despite the fact that goats form an important component of livestock population in Ethiopia, little attention has been given to improve the productivity of the species (Kassahun et al., 1989). FAO (2001) estimated that average dressed carcass output per individual goat in Ethiopia is $8 \mathrm{~kg}$, which is among the lowest in African countries.

Because of the poor quality of natural pasture and crop residues, substantial weight loss of animals is encountered, especially during dry seasons. This cyclical pattern of weight gain and lose based on the availability of feed across the season can be mitigated by identifying, evaluating, and using of the locally available non- conventional feeds that can be used during periods of feed scarcity.

Among crop residues available for animal feeding are groundnut pod hulls. Groundnut pod hulls are extensively fed to ruminants, especially in dry seasons (Olorunju et al., 1996). Groundnut pod hulls contain crude protein (CP) of $115 \mathrm{~g} / \mathrm{kg} \mathrm{DM}$, which is higher as compared to hulls of other legumes such as cotton seed hulls. Nevertheless, the majority of groundnut pod hulls produced in Ethiopia are either dumped or used as fire fuel.

Despite the fact that groundnut pod hull is produced in many districts of low lands of Ethiopia, system for its utilization as animal feed has not been developed and made available to small scale farmers. Moreover, the effect of feeding groundnut pod hulls as a basal diet and its supplementation with mixture of concentrate was not 
investigated in the diet of goats. Therefore, this study was designed to come up with the effect of urea treated groundnut pod hulls and supplementation of the untreated groundnut pod hulls with wheat bran and mustard seed cake mixture on body weight change, carcass, and edible and non-edible non-carcass yield performance of Somali goats.

\section{MATERIALS AND METHODS}

\section{Descriptions of the Study Area}

The study was conducted in Kombolcha ATVET College which is located in Kombolcha district, Eastern Hararghe Zone of the Oromia National Regional State, Ethiopia. It is located at $542 \mathrm{~km}$ East of Addis Ababa and $17 \mathrm{~km}$ North of Harar town. It lies within an altitude ranging from 1200 to 2460 m.a.s.l, at latitude of $42^{\circ} 07^{\prime \prime} 0$ $E$ and longitude of $9^{\circ} 25^{\prime \prime} 60^{\prime} \mathrm{N}$. The rainfall pattern of the site is bimodal, erratic, and unreliable with the mean annual precipitation ranging from $600-900 \mathrm{~mm}$. The long rainy season 'keremt' starts at the beginning of July and extends up to September, while the short rainy season 'belg' is from March up to April and the mean annual temperature range from $16-25^{\circ} \mathrm{C}$.

\section{Management of Animals and Experimental Design}

A total of 30 Somali goats were quarantined for 15 days, of which 25 goats were selected and used for the experiment. The quarantine period was followed by 15 days of acclimatization to the experimental diets and pen during which the goats were kept and fed in individual pens. A completely randomized block design was used for the experiment. The goats were grouped into five blocks of five goats each based on their initial bodyweight. Goats in each block were randomly assigned to one of the five treatment diets.

Treatment feed consisted of untreated groundnut pod hulls ad libitum (T1, control), urea treated groundnut podhulls ad libitum (T2), and supplementation of untreated groundnut pod hulls with $125 \mathrm{~g}$ (T3), $250 \mathrm{~g}$ (T4), and $375 \mathrm{~g}$ (T5). The supplement feed was mixed at the ratio of $75.1 \%$ wheat bran (WB) to $24.9 \%$ mustard seed cake (MSC) that is a $3: 1$ ratio. The supplement mixtures were offered twice per day in equal part at 08:00 and 16:00hours. Experimental animals had free access to salts of mineral blocks and water throughout the experimental period. The BW of experimental goats was measured at ten days intervals in the morning hours before feeding and watering. Feed intake was recorded for 90 experimental days and chemical content was measured.

\section{Chemical Analysis}

The chemical analysis of the experimental feeds offered, refusals and feces were carried out after taking representative samples. Samples of the feeds offered, refused and feces were ground to pass a $1 \mathrm{~mm}$ sieve mesh. Dry matter, Organic matter (OM), and ash were analyzed based on AOAC (1990) procedure. Analysis for Kjeldhal nitrogen content was run according to AOAC (1990) procedure and the Crude Protein (CP) content was determined by multiplying nitrogen content by a factor of 6.25. Neutral detergent fiber (NDF), Acid detergent fiber (ADF), and Acid detergent lignin (ADL) was analyzed by using the procedures of Van Soest and Robertson (1985). Hemi-cellulose was calculated as NDF-ADF and cellulose was calculated as ADF-ADL.

\section{Carcass Parameters Determination}

Before slaughtering, all goats from each treatment were denied any access to feeds on average for 14 hours in order to minimize variation in gut fill. All the twenty-five goats were slaughtered and carcass parameters were evaluated at the end of the experimental period. The carcass was eviscerated and the internal organs and tissues were weighed. Weight of body components such as head, forefeet with hooves, skin, kidneys, and liver with bile, heart, lungs, testis and spleen were taken separately during the slaughter process.

The weight of the gastro-intestinal tract were recorded prior to and after emptying its contents. Heart fat, kidney fat, omental fat, and mesenteric fat weights were taken by sensitive balance. After removal of non-carcass parts, the hot carcass was weighed and recorded for each goat. Empty body weight (EBW) was calculated by deducting weight of gut content from live weight. Dressing percentage of the carcass was calculated based on preslaughter fasting BW and empty BW. Dressing percentage was expressed both as proportion of hot carcass weight to slaughter weight and hot carcass weight to empty BW. The carcass was cut longitudinally into two halves along the spine and both the right and left halve was cut between the $12^{\text {th }}$ and $13^{\text {th }}$ rib perpendicularly to the back-bone to measure the cross sectional area of the longissimus dorsi (rib-eye muscle). The cross section of the rib-eye muscle was traced on water proof transparency paper and the area of the squares that fell within the traced area was counted on graph paper and the average of the two rib-eye muscle areas were taken for each goat. The sum of blood, liver with gall bladder, kidneys, heart, tongue, testicle, body fat, reticulorumen, omasum and abomasums, and intestines were taken as edible offal component whereas, the sum of head, skin with feet, lung, trachea, and esophagus, spleen and penis were taken as non-edible offal components.

\section{Statistical Analysis}

Experimental data collected were analyzed using the analysis of variance model for completely randomized block design by employing the general linear model procedure of SAS (2004) version 9.0. Differences between treatment means were tested using least significant difference (LSD) test. The model that was used for the analysis was:

$$
Y_{i j}=\mu+T_{i}+B_{j}+E_{i j}
$$

Where, $Y_{i j}=$ the response variable, $\mu$ is overall mean, $T_{i}$ is treatment effect, $B_{j}$ is block effect and $E_{i j}$ is random error.

\section{RESULTS \\ Chemical Composition of Diet}

Untreated groundnut pod hulls contained $87.9 \%$ Organic matter (OM), 8.9\% Crude protein(CP), 79.0\% Neutral detergent fiber (NDF), and70.3\% Acid detergent fiber (ADF). The urea treated groundnut pod hulls contained $88.9 \%$ Organic matter (OM), $11.4 \%$ Crude protein(CP), 75.6\% Neutral detergent fiber(NDF), and72.7\% Acid detergent fiber (ADF). The chemical content of mustard seed cake and wheat bran mixture was94.4\% Organic matter (OM), 21.4\% Crude protein(CP), 33.9\% Neutral detergent fiber (NDF), 11.3\% Acid detergent fiber (ADF).

\section{Feed Intake}

Untreated ground nut pod hulls (UGNPH) DM intake was higher $(P<0.001)$ in T1 thanT4 and T5. But it is lower 
Tesfaye and Mengistu

than the intake of urea treated groundnut pod hulls (UTGNPH) (T2). There was no difference in the hull DM intake ( $P>0.05)$ between goats fed UGNPH and T3. The DM intake of UTGNPH was higher $(P<0.001)$ as compared to the UGNH.

The total DM intake was significantly different between the treatments $(P<0.001)$ in the order of $\mathrm{T} 1<\mathrm{T} 2<\mathrm{T} 3<\mathrm{T} 4$ $<$ T5. Total OM intake significantly $(P<0.001)$ increased with the level of supplementation and group fed with urea treated hull consumed more compared to those consumed the untreated pod hull. Organic matter intake was higher in T5 than the other treatments, and T4 consumed higher amount of OM compared to T1, T2, and T3, while there was no difference in the amount of OM consumed by T2 and T3.The total CP intake increased
Sci. Technol. Arts Res. J., Jan-March 2014, 3(1): 57-63

with level of supplementation and differed $(P<0.001)$ between treatments in the order of $\mathrm{T} 5>\mathrm{T} 4>\mathrm{T} 3>\mathrm{T} 2>\mathrm{T} 1$.

\section{Body Weight Change}

Supplemented goats had higher $(P<0.001)$ final BW than goats fed urea treated and untreated groundnut pod hulls. Among supplemented groups, goats in T5 had higher $(P<0.001)$ final BW and daily BW gain than T3 and T4.

Goats that consumed sole untreated and urea treated groundnut pod hulls have lost 30 and $6 \mathrm{~g}$ per day, respectively. Increasing level of supplementation resulted in higher $(P<0.001)$ daily BW gain. The higher BW gain recorded in $\mathrm{T} 5$ and $\mathrm{T} 4$ could be attributed to both higher intake of energy and protein, hence feed utilization efficiency than the other treatments.

Table 1: Daily dry matter and nutrient intake of Somali goats fed untreated groundnut pod hulls and supplemented with different levels of wheat bran and mustard seed cake and sole urea treated groundnut pod hulls

\begin{tabular}{|c|c|c|c|c|c|c|c|}
\hline Parameters & T1 & T2 & T3 & T4 & T5 & SEM & SL \\
\hline GNPHDM intake $(\mathrm{g} / / \mathrm{h} / \mathrm{d})$ & $407.3^{\mathrm{b}}$ & $471.1^{a}$ & $388.7^{b}$ & $331.5^{c}$ & $272.1^{d}$ & 18.50 & *** \\
\hline CDMI intake (g/h/day) & - & - & 125.0 & 250.0 & 375.0 & & \\
\hline TDM intake ( $\mathrm{g} / \mathrm{h} /$ day) & $407.3^{\mathrm{e}}$ & $471.1^{d}$ & $513.8^{\mathrm{C}}$ & $581.4^{\mathrm{b}}$ & $647.1^{\mathrm{a}}$ & 11.27 & *** \\
\hline OM intake (g/h/day) & $339.3^{d}$ & $414.9^{c}$ & $431.9^{c}$ & $486.1^{\mathrm{b}}$ & $538.7^{\mathrm{a}}$ & 8.19 & *** \\
\hline CP intake (g/h/day) & $43.9^{\mathrm{e}}$ & $60.2^{\mathrm{d}}$ & $69.3^{\mathrm{c}}$ & $87.5^{\mathrm{b}}$ & $110.0^{\mathrm{a}}$ & 1.29 & *** \\
\hline EME intake (MJ/d) & $3.1^{\mathrm{c}}$ & $3.2^{\mathrm{c}}$ & $3.8^{\mathrm{b}}$ & $4.3^{\mathrm{ab}}$ & $4.7^{\mathrm{a}}$ & 0.11 & ** \\
\hline DM intake (g/kg W $\left.{ }^{0 . / 5}\right)$ & $46.8^{\mathrm{e}}$ & $53.3^{d}$ & $55.8^{\mathrm{C}}$ & $61.74^{\mathrm{b}}$ & $65.5^{\mathrm{a}}$ & 0.14 & *** \\
\hline
\end{tabular}

$\mathrm{a}, \mathrm{b}, \mathrm{c}, \mathrm{d}, \mathrm{e}$ means within a row not bearing a similar superscript letter are significantly different. ${ }^{\star *}=(P<0.01) ;{ }^{\star \star \star}=(P<0.001) ; \mathrm{CDM}=\mathrm{concentrate}$ dry matter; $\mathrm{CP}=$ crude protein; $\mathrm{DM}=$ dry matter; $\mathrm{GNPH}=$ groundnut pod hulls; $\mathrm{ns}=$ non-significant $\mathrm{EME}=$ estimated metabolizable energy intake; $\mathrm{OM}=$ organic matter; SEM = standard error of means; $\mathrm{SL}=$ significance level; $\mathrm{T} 1=$ untreated groundnut hulls alone; $\mathrm{T} 2=$ urea treated groundnut hulls alone; $\mathrm{T} 3=$ untreated groundnut hulls $+125 \mathrm{~g} \mathrm{DM} / \mathrm{head} /$ day concentrate $\mathrm{mix} ; \mathrm{T} 4=$ untreated groundnut hulls $+250 \mathrm{~g} \mathrm{DM} / \mathrm{head} / \mathrm{day} \mathrm{concentrate} \mathrm{mix} ; \mathrm{T} 5=\mathrm{un}$ treated groundnut hulls $+375 \mathrm{~g} \mathrm{DM} /$ head/day concentrate mix.

Table 2: Body weight change and feed conversion efficiency of Somali goats fed untreated groundnut pod hulls and supplemented with different levels of mixture of wheat bran and mustard seed cake and sole urea treated groundnut pod hulls

\begin{tabular}{llllllll}
\hline Parameters & T1 & T2 & T3 & T4 & T5 & SEM & SL \\
\hline Initial BW $(\mathrm{kg})$ & 18.5 & 18.5 & 18.4 & 18.0 & 18.7 & 0.09 & $\mathrm{~ns}$ \\
Daily BW gain/loss $(\mathrm{g} / \mathrm{d})$ & $-30.2^{\mathrm{e}}$ & $-6.7^{\mathrm{d}}$ & $18.9^{\mathrm{c}}$ & $40.7^{\mathrm{b}}$ & $53.3^{\mathrm{a}}$ & 4.16 & $\star \star \star$ \\
Final BW $(\mathrm{kg})$ & $15.8^{\mathrm{e}}$ & $17.8^{\mathrm{d}}$ & $20.1^{\mathrm{c}}$ & $21.7^{\mathrm{b}}$ & $23.5^{\mathrm{a}}$ & 0.11 & $\star \star \star$
\end{tabular}

a, b, c, d, e means within a row not bearing a similar superscript letter are significantly different. ${ }^{\star \star *}=(\mathrm{P}<0.001)$; BW= body weight; FCE $=$ feed conversion efficiency; ns = non-significant; SEM = standard error of means; $\mathrm{SL}=$ significance level; $\mathrm{T} 1$ = untreated groundnut hulls alone; $\mathrm{T} 2=$ urea treated groundnut hulls alone; T3 = untreated groundnut hulls $+125 \mathrm{~g} \mathrm{DM} / \mathrm{head} /$ day concentrate $\mathrm{mix} ; \mathrm{T} 4=$ untreated groundnut hulls $+250 \mathrm{~g} \mathrm{DM} / \mathrm{head} / \mathrm{day}$ concentrate $\mathrm{mix}$; $\mathrm{T} 5=$ untreated groundnut hulls $+375 \mathrm{~g} / \mathrm{head} /$ day concentrate mix.

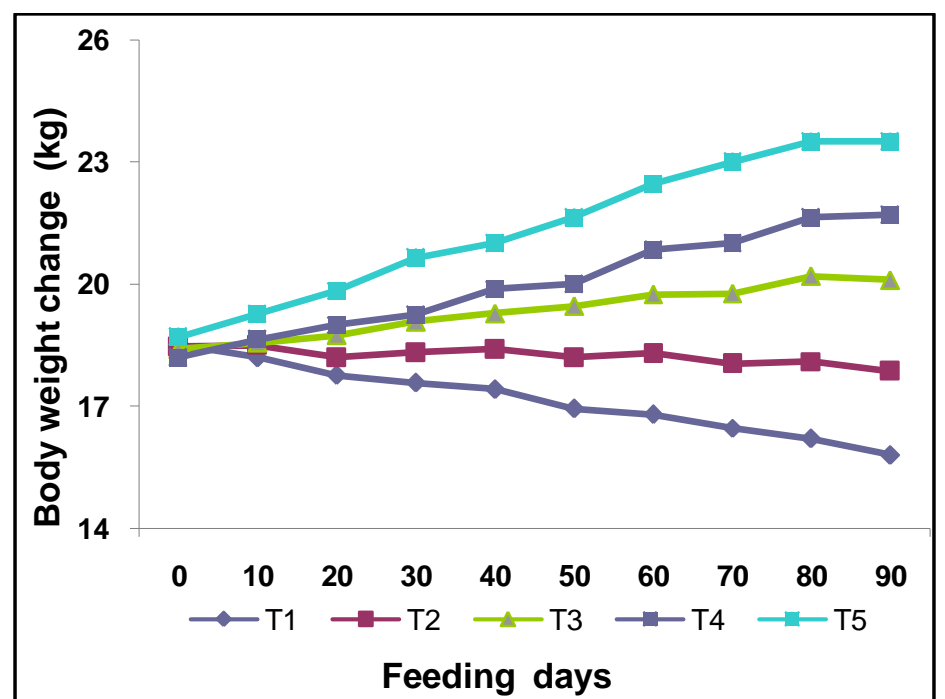

$\mathrm{T} 1$ = untreated groundnut pod hulls alone; T2 = urea treated groundnut pod hulls alone; T3 = untreated groundnut hulls $+125 \mathrm{~g}$ DM/head/day CM; T4= untreated groundnut hulls $+250 \mathrm{~g} \mathrm{DM} /$ head/day CM; T5 = untreated groundnut hulls $+375 \mathrm{~g} \mathrm{DM} / \mathrm{head} /$ day concentrate $\mathrm{mix}$.

Figure 1: Trends in body weight change across the feeding days of Somali goats fed untreated groundnut pod hulls and supplemented with different levels of mixture of wheat bran and mustard seed cake or sole urea treated groundnut pod hulls. 


\section{Carcass Parameters}

Slaughter BW and hot carcass weight were different $(P<0.001)$ among all treatments (Table 3$)$. The slaughter BW and hot carcass weight were higher $(P<0.001)$ for supplemented groups as compared to non-supplemented groups (T2 and T1). Among the supplemented groups, these parameters are higher in the order T5 $>$ T4 $>$ T3. T4 and T5 had higher $(P<0.001)$ empty body weight compared to T1, T2, and T3, whereas T2 and T3 were similar in empty BW and higher $(P<0.001)$ than $\mathrm{T} 1$.
Dressing percentage on slaughter BW was higher $(P<0.01)$ for supplemented group as compared to groups fed sole untreated groundnut pod hulls, but similar results were obtained among supplemented goats. Goats fed untreated groundnut pod hulls alone had lower $(P<0.01)$ dressing percentage on empty BW base compared with those fed sole urea treated groundnut pod hulls and the supplemented group. Rib eye area was similar between T4 and T5 and higher $(P<0.001)$ than the other treatments. Likewise, T2 and T3 did not differ $(P>0.05)$ in rib eye area and higher than that of $\mathrm{T} 1$.

Table 3: Carcass characteristics of Somali goats fed untreated groundnut pod hulls supplemented with different levels of mixture of wheat bran and mustard seed cake and sole urea treated groundnut pod hulls

\begin{tabular}{lccccccc}
\hline \multicolumn{1}{c}{ Parameters } & T1 & T2 & T3 & T4 & T5 & SEM & SL \\
\hline Slaughter BW $(\mathrm{kg})$ & $15.8^{\mathrm{e}}$ & $17.8^{\mathrm{d}}$ & $20.1^{\mathrm{c}}$ & $21.7^{\mathrm{b}}$ & $23.5^{\mathrm{a}}$ & 0.12 & ${ }^{* *}$ \\
Empty BW (kg) & $8.76^{\mathrm{d}}$ & $12.1^{\mathrm{c}}$ & $14.1^{\mathrm{c}}$ & $17.2^{\mathrm{b}}$ & $18.9^{\mathrm{a}}$ & 0.24 & $* * *$ \\
Hot carcass weight $(\mathrm{kg})$ & $5.6^{\mathrm{e}}$ & $7.1^{\mathrm{d}}$ & $8.0^{\mathrm{c}}$ & $8.9^{\mathrm{b}}$ & $9.7^{\mathrm{a}}$ & 0.07 & $* * *$ \\
Dressing percentage (\%) & & & & & & & \\
$\quad$ Slaughter BW base & $35.4^{\mathrm{b}}$ & $38.0^{\mathrm{ab}}$ & $39.4^{\mathrm{a}}$ & $40.9^{\mathrm{a}}$ & $41.1^{\mathrm{a}}$ & 2.21 & $* *$ \\
$\quad$ Empty BW base & $47.1^{\mathrm{b}}$ & $54.8^{\mathrm{a}}$ & $57.6^{\mathrm{a}}$ & $58.1^{\mathrm{a}}$ & $58.9^{\mathrm{a}}$ & 4.57 & ${ }^{* *}$ \\
Rib-eye muscle area $\left(\mathrm{cm}^{2}\right)$ & $4.3^{\mathrm{c}}$ & $5.9^{\mathrm{b}}$ & $5.8^{\mathrm{b}}$ & $7.3^{\mathrm{a}}$ & $7.7^{\mathrm{a}}$ & 0.05 & $* * *$
\end{tabular}

a, b, c, d, e means within a row not bearing a similar superscript letter are significantly different. ${ }^{\star \star \star}=(P<0.001) ;{ }^{\star \star}=(P<0.01)$; BW $=$ body weight; SEM $=$ standard error of means; $\mathrm{SL}=$ significant level; $\mathrm{T} 1=$ untreated groundnut hulls; $\mathrm{T} 2=$ urea treated groundnut hulls; $\mathrm{T} 3=$ untreated groundnut hulls $+125 \mathrm{~g}$ $\mathrm{DM} /$ head/day concentrate mix; T4 $=$ untreated groundnut hulls $+250 \mathrm{~g} \mathrm{DM}$ head/day concentrate $\mathrm{mix} ; \mathrm{T} 5=$ untreated groundnut hulls $+375 \mathrm{~g}$ DM/head/day concentrate mix.

\section{Edible Offal Components}

Goats in supplemented group had higher weight of blood $(P<0.01)$ and kidneys $(P<0.001)$ as compared to non-supplemented group (Table 4). T5 had higher weight of liver with gall bladder, large and small intestine and testicle $(P<0.001)$, tongue $(P<0.01)$ compared to lower and medium level of supplementation (T3 and T4) and non-supplemented group (T1 and T2). This could possibly be explained by the fact that supplementation had a positive effect on the edible offal components. Heart fat, omental and mesenteric fat, and abomasum were different $(P<0.001)$ in the order of $\mathrm{T} 1<\mathrm{T} 2<\mathrm{T} 3<\mathrm{T} 4=\mathrm{T} 5$. Goats in T5 and T4 recorded higher weight of heart $(P<0.001)$ as compared to goats in T1, T2, and T3. No difference was observed ( $P>0.05)$ for omasum. Heavier total edible offal $(P<0.001)$ was obtained for higher and medium level supplemented (T4 and T5) groups as compared to T1, T2, and T3.

Table 4:Edible offal components of Somali goats fed untreated groundnut pod hulls and supplemented with different levels of mixture of wheat bran and mustard seed cake and sole urea treated groundnut pod hulls

\begin{tabular}{|c|c|c|c|c|c|c|c|}
\hline Parameter & T1 & T2 & T3 & T4 & T5 & SEM & SL \\
\hline Blood $(\mathrm{g})$ & $642.0^{b}$ & $704.0^{b}$ & $906.0^{\mathrm{a}}$ & $1020.0^{\mathrm{a}}$ & $1030^{\mathrm{a}}$ & 22.27 & ** \\
\hline Liver with gall bladder ( $\mathrm{g}$ ) & $232.0^{\mathrm{C}}$ & $266.0^{\mathrm{bc}}$ & $265.0^{\mathrm{bc}}$ & $299.0^{b}$ & $468.0^{\mathrm{a}}$ & 11.36 & *** \\
\hline Kidneys (g) & $59.0^{\mathrm{b}}$ & $60.0^{\mathrm{b}}$ & $73.4^{\mathrm{a}}$ & $75.0^{\mathrm{a}}$ & $78.0^{\mathrm{a}}$ & 2.22 & *** \\
\hline Heart $(\mathrm{g})$ & $47.0^{\mathrm{C}}$ & $61.0^{\mathrm{cb}}$ & $74.0^{\mathrm{b}}$ & $97.0^{\mathrm{a}}$ & $94.0^{\mathrm{a}}$ & 14.85 & *** \\
\hline Tongue $(\mathrm{g})$ & $37.6^{c}$ & $42.2^{b c}$ & $51.6^{\mathrm{bc}}$ & $56.6^{b}$ & $78.0^{\mathrm{a}}$ & 15.26 & ** \\
\hline Testicle (g) & $136.0^{c}$ & $149.0^{c}$ & $158.0^{\mathrm{bc}}$ & $181.0^{\mathrm{b}}$ & $222.0^{\mathrm{a}}$ & 25.29 & $* * *$ \\
\hline Kidney fat (g) & $5.2^{\mathrm{C}}$ & $36.9^{\mathrm{b}}$ & $43.0^{\mathrm{ab}}$ & $48.2^{\mathrm{a}}$ & $52.0^{\mathrm{a}}$ & 16.03 & *** \\
\hline Heart fat $(\mathrm{g})$ & $7.1^{d}$ & $16.5^{\mathrm{c}}$ & $27.3^{b}$ & $33.1^{\mathrm{a}}$ & $37.5^{\mathrm{a}}$ & 11.41 & *** \\
\hline Omental and mesenteric fat $(\mathrm{g})$ & $55.8^{d}$ & $70.8^{c}$ & $97.5^{\mathrm{b}}$ & $125.1^{\mathrm{a}}$ & $127.8^{\mathrm{a}}$ & 13.51 & *** \\
\hline Reticulorumen $(\mathrm{g})$ & $380.0^{d}$ & $395.0^{\text {cd }}$ & $436.0^{\mathrm{bc}}$ & $468.0^{\mathrm{ab}}$ & $498.0^{\mathrm{a}}$ & 18.02 & *** \\
\hline Omasum (g) & 114.0 & 120.0 & 128.0 & 116.0 & 176.0 & 2.09 & ns \\
\hline Abomasums $(\mathrm{g})$ & $79.0^{d}$ & $88.2^{\mathrm{C}}$ & $105.8^{\mathrm{b}}$ & $117.6^{\mathrm{a}}$ & $121.0^{\mathrm{a}}$ & 11.44 & *** \\
\hline Large and small intestines ( $\mathrm{g}$ ) & $564.0^{\mathrm{C}}$ & $575.0^{b}$ & $442.0^{\mathrm{C}}$ & $583.0^{b}$ & $792.0^{\mathrm{a}}$ & 33.10 & *** \\
\hline TEOC $(\mathbf{k g})$ & $2.4^{\mathrm{d}}$ & $2.6^{\mathrm{cd}}$ & $2.8^{\mathrm{c}}$ & $3.2^{\mathrm{b}}$ & $3.8^{\mathrm{a}}$ & 0.10 & *** \\
\hline
\end{tabular}

a, b, c, d means within a row not bearing a similar superscript letter are significantly different. ${ }^{* *}=(P<0.001) ;{ }^{* *}=(P<0.01)$; ns $=$ not significant; SEM $=$ standard error of means; SL = significant level; TEOC = total edible offal components; T1 = untreated groundnut hulls alone; $\mathrm{T} 2$ = urea treated groundnut hulls alone; T3 = untreated groundnut hulls $+125 \mathrm{~g} \mathrm{DM} /$ head/day concentrate $\mathrm{mix} ; \mathrm{T} 4=$ untreated groundnut hulls $+250 \mathrm{~g} \mathrm{DM} / \mathrm{head} / \mathrm{day}$ concentrate $\mathrm{mix} ;$ $\mathrm{T} 5=$ untreated groundnut hulls $+375 \mathrm{~g} \mathrm{DM} / \mathrm{head} /$ day concentrate mix.

\section{Non Edible Offal Components}

Head without tongue was higher $(P<0.01)$ in supplemented groups as compared to non-supplemented groups, but results obtained were not significant $(P>0.05)$ between non-supplemented group (T1 and T2). Skin with feet was higher $(P<0.05)$ for T4 and T5 with lack of significant difference between non-supplemented groups and groups fed the medium and high level of supplementation for the same parameters. Lung, trachea, and esophagus were $(P<0.001)$ higher in T5, compared to the other treatments.

Gut contents of goats fed untreated groundnut pod hulls (T1) and urea treated groundnut pod hulls (T2) were higher $(P<0.001)$ than the supplemented groups. The gut contents as proportion of BW of goats obtained in the 
present study were $(P<0.001)$ higher for untreated and urea treated than supplemented treatments. Total nonedible offal components were higher $(P<0.001)$ in the nonsupplemented groups as compared to supplemented groups, and no significance differences was ( $P>0.05)$ observed among the supplemented and between the nonsupplemented groups.

Table 5: Non edible offal components of Somali goats fed untreated groundnut pod hulls and supplemented with different levels of mixture of wheat bran and mustard seed cake or sole urea treated groundnut pod hulls

\begin{tabular}{|c|c|c|c|c|c|c|c|}
\hline Parameter & T1 & $\mathbf{T}_{2}$ & $\mathbf{T}_{3}$ & $\mathrm{~T}_{4}$ & $\mathrm{~T}_{5}$ & SEM & SL \\
\hline Head without tongue $(\mathrm{g})$ & $1120.0^{c}$ & $1218.0^{c}$ & $1320.0^{b}$ & $1510.0^{\mathrm{a}}$ & $1333.0^{\mathrm{ab}}$ & 12.09 & ** \\
\hline Skin with feet $(\mathrm{g})$ & $1520.0^{b}$ & $1536.0^{b}$ & $1727.0^{\mathrm{ab}}$ & $2086.0^{a}$ & $1982.0^{\mathrm{a}}$ & 48.29 & * \\
\hline Spleen $(\mathrm{g})$ & 44.0 & 52.0 & 42.0 & 63.0 & 51.0 & 56.27 & ns \\
\hline Lung, trachea, and esophagus ( $\mathrm{g}$ ) & $183.0^{\mathrm{b}}$ & $185.0^{\mathrm{b}}$ & $189.0^{\mathrm{b}}$ & $193.0^{\mathrm{b}}$ & $240.0^{\mathrm{a}}$ & 69.37 & *** \\
\hline Penis $(g)$ & 41.0 & 47.0 & 50.0 & 50.4 & 62.2 & 58.17 & ns \\
\hline TNEOC (kg) & $3.1^{\mathrm{a}}$ & $3.1^{\mathrm{a}}$ & $2.3^{\mathrm{b}}$ & $2.6^{\mathrm{b}}$ & $2.3^{\mathrm{b}}$ & 0.04 & *** \\
\hline Gut content $(\mathrm{kg})$ & $5.8^{\mathrm{a}}$ & $5.6^{\mathrm{a}}$ & $4.2^{\mathrm{b}}$ & $4.6^{\mathrm{b}}$ & $4.6^{\mathrm{b}}$ & 0.06 & $* * *$ \\
\hline Gut content, $(\%$ SW) & $36.1^{\mathrm{a}}$ & $30.0^{\mathrm{b}}$ & $20.6^{c}$ & $21.1^{\mathrm{c}}$ & $19.5^{c}$ & 1.18 & $* * *$ \\
\hline
\end{tabular}

a, b, c, d means within a row not bearing a similar superscript letter are significantly different. ${ }^{\star * *}=(P<0.001) ;{ }^{* *}=(P<0.01) ;{ }^{*}=(P<0.05) ; \mathrm{SEM}=$ standard error of means; SL = significant level; SW = slaughter weight; TNEOC = total non-edible offal components; T1= untreated groundnut hulls alone; T2 = urea treated groundnut hulls alone; T3 = untreated groundnut hulls $+125 \mathrm{~g} / \mathrm{head} / \mathrm{day}$ concentrate $\mathrm{mix}$; T4 = untreated groundnut hulls $+250 \mathrm{~g} \mathrm{DM} / \mathrm{head} /$ day concentrate $\mathrm{mix} ; \mathrm{T} 5=$ untreated groundnut hulls $+375 \mathrm{~g} \mathrm{DM} / \mathrm{head} / \mathrm{day}$ concentrate mix

\section{DISCUSSION}

\section{Feed Intake}

Supplementation may improve the total DM intake by supplying fermentable carbohydrates or proteins for the cellulolytic microbes upon degradation in the rumen. The low intake of total DM by goats in T1 and T2 is partly explained by the relatively low CP contents of UGNPH and UTGNPH. However, higher DM and OM intake in the group that consumed UTGPH as compared to the group consumed sole UGNPH indicates the advantage of urea treatment as evidenced by the relatively improved $\mathrm{CP}$ content of the roughage.

Mbaye and Sall (1982) reported that supplementation of sheep and cattle with brewer grains and molasses improved the total DM intake than those fed sole untreated groundnut hulls. Likewise, Matiwos et al. (2008) reported that total DM intake and growth rate of Sidama goats increased correspondingly as level of cottonseed meal increased. In agreement with the result of this study, Liu et al. (1998) reported that supplementation of sheep with different levels of rapeseed meal $(88,175$, and 262) $\mathrm{g} / \mathrm{h} / \mathrm{d}$ improved the total DM intake than those fed untreated rice straw basal diet. The increased CP intake with supplementation in the current study was in accordance with study conducted by Titi et al. (2000) in which total CP intake of Awassi lambs increased with the level of $\mathrm{CP}$.

\section{Body Weight Change}

The higher BW gain recorded in T5 and T4 could be attributed to both higher intake of energy and protein, hence feed utilization efficiency than the other treatments. The supplement feed provided energy and protein which are critical for the growth of goats. Protein supplementation improved rumen environment through increased ammonia concentration and available energy as a result of higher DM intake, thus improved microbial activity and the resultant digestibility (Osuji et al., 1995; Kariuki, 1998). This was reflected in improved growth and efficiency with which the feed was utilized in the supplemented compared to non-supplemented groups (T2 and T1) of the current experiment. Mahgoub et al. (1984) reported that groundnut hulls, when used as basal diets and supplemented with urea and molasses, can give sheep performances comparable to conventional (high grain) feeds. In line with this finding, Simret and Solomon (2009) reported BW loss of $31 \mathrm{~g} / \mathrm{d}$ in Somali goats fed sole grass hay and daily BW gain of 39.9-44.7 g/d when they were supplemented with groundnut cake and wheat bran. Contrary to this finding Ebong (1996) reported daily BW gain of $27.1 \mathrm{~g} / \mathrm{d}$ in goats fed sole Elephant grass and $67 \mathrm{~g} /$ day when they were supplemented on Calliandra leaf meal, which in this case could be the high quality of the elephant grass.

Hango et al. (2007) reported that supplementation of Small East African goat with 12, 18, and $24 \mathrm{~g} \mathrm{DM} /$ day concentrate mixture gained at the rate of $29.2,44.5$, and $50.5 \mathrm{~g} / \mathrm{d}$, but, those goats fed a basal diet of Chlorisgayana hay ad libitum gained only $12 \mathrm{~g} / \mathrm{d}$. Similar to the current finding Wambui et al. (2006) reported BW loss of $3 \mathrm{~g} / \mathrm{d}$ in a cross breed bucks (German $\times$ Small East African goats) fed urea treated maize stover consisting of $8.3 \% \mathrm{CP}$, while the supplemented group showed remarkable gain. Furthermore, Ayoade (2002) reported that supplementation of goats with graded levels of maize bran promoted weight gain, but those fed basal diet of pigeon pea hulls containing of $7.7 \% \mathrm{CP}$, that is comparable with $8.9 \% \mathrm{CP}$ content of groundnut pod hulls used in this study, had lost weight at a rate of $7 \mathrm{~g} / \mathrm{d}$.

Goats fed with untreated (T1) and urea treated (T2) groundnut pod hulls were unable to maintain their body weight throughout the experimental period, despite the fact that treatment diet have 8.9 and $11.4 \%$ CP content, respectively, which is a level comparable to and slightly above the recommended CP required for rumen microbial function and the minimum requirement $(7 \% \quad \mathrm{CP})$ for maintenance. The negative growth rates recorded by goats fed untreated and urea treated groundnut pod hulls alone might be attributed to the unavailability of protein in the hulls because of its low digestibility. The CP requirement of goats for maintenance, based on an average of published data, is $4.15 \mathrm{~g} / \mathrm{kgW}^{0.75}$, with an average digestibility of $68 \%$ (Merck, 2008). Therefore, the $\mathrm{CP}$ digestibility of the non-supplemented treatments (T1 and T2) was 62 and $64 \%$, respectively, the values which are lower than recommended in literature. Additionally, the negative growth rate may have been typically attributed to low energy provision by the hulls. Such diets result in increased nitrogen intake increased nitrogen 
Tesfaye and Mengistu

excretion, but no significant improvement in nitrogen balance or growth (Shoo, 1986; Muhikambele, 1990). Moreover, Vanes (1979) reported that not only CP content, but also the quantity of protein together with the energy utilization will determine growth.

\section{Carcass Parameters}

Edible Offal Components: Heavier total edible offal $(P<0.001)$ was obtained for higher and medium level supplemented (T4 and T5) groups as compared to T1, T2, and T3. This clearly suggests that supplementation increased total edible offal. This was in agreement with the work of Hirut (2008) in which higher total edible offal components was observed for the supplemented groups than the sheep fed urea treated diet alone. Moreover, Matwos et al. (2008) also reported that supplementation of Sidama goats has a positive effect on the weight of most edible offal components. Generally, nutritional status of the animals and BW affects the production efficiency of the offal (Kirton et al., 1995). Overall, in the present study, total edible offal components increased with increased concentrate allowance.

Non Edible Offal Components: Gut contents of goats fed untreated groundnut pod hulls (T1) and urea treated groundnut pod hulls (T2) were higher $(P<0.001)$ than the supplemented groups. This may be because of the high level of cell wall fraction in the diet consumed by the nonsupplemented treatment groups, which is less digestible and hence leading to high gut content. The relative reduction in the dressing percentage of $\mathrm{T} 1$ and $\mathrm{T} 2$ might be due to the reduction in hot carcass weight and increased gut fill (Table 3). In line with this finding, a study done by Humphreys (1991) indicated higher gut content of goats fed tropical pasture than supplemented groups. Moreover, Mesfin (2007) reported that, Arsi-Bale goats fed feedlot fattening ration from 12 month of age up to a slaughter BW of $25.3 \mathrm{~kg}$, had a gut fill of $4.89 \mathrm{~kg}(19.3 \%$ of slaughter BW) which is comparable to the average gut content of the current study, which is $4.96 \mathrm{~kg}$.

\section{CONCLUSION}

The result of the study reveals the merits of supplementation of groundnut pod hulls. Supplementation with mixture of wheat bran and mustard seed cake improved body weight gain, dressing percentage, and production of higher edible offal's. From the present result, it can be concluded that high crude protein content of feed alone does not ensure or grant better animal performance unless it is efficiently utilized by the animals for the required purpose. Feeding of urea treated groundnut pod hulls alone could not promote animals' performance unless supplemented with some concentrate.

\section{REFERENCE}

Ayoade, J. A. (2002). The effect of maize bran on voluntary intake and digestibility of pigeon pea (Cajanuscajan) hulls by goats. African Research Network for Agricultural Byproducts Newsletter 2(3):6. ILCA, Addis Ababa, Ethiopia.

AOAC (Association of Official Analytical Chemists), 1990. Official method of analysis. $15^{\text {th }}$ (ed.). AOAC Inc. Arlington, Virginia, USA. Pp. 12-98.

Ebong, C. (1996). Calliandra leaf meal in goat rations: effects on protein degradability in the rumen and growth in goats. In: Small Ruminant Research and Development in Africa.
Sci. Technol. Arts Res. J., Jan-March 2014, 3(1): 57-63

Proceedings of the $3^{\text {rd }}$ Biennial Conference SRNET, UICC, Kampala, Uganda, $5^{\text {th }}-9^{\text {th }}$, December 1994. Lebbies SHB and Kangwine (eds.). pp 227-229.

FAO. (1999). Production Year Book. Food and Agricultural Organization. Rome, Italy, Vol. 2.Pp. 98.

FAO.(2001). Production Year Book. Food and Agricultural Organization. Rome, Italy, Vol.3.p.17.

Farm-Africa (1996). Goat types of Ethiopia and Eritrea. Physical description and management systems. Published jointly by Farm-Africa, London, UK, and IRLI (International Livestock Research Institute), Nairobi, Kenya.Pp.76.

Hango, L.A., Mtenga, G.C., Kifaro, J., Safari, D.E., Mushi and Muhikambele, V.R.M. (2007). A study on growth performance and carcass characteristics of Small East African goats under different feeding regimes. Tanzania Journal of Agricultural Sciences 5(1): 29-38.

Hirut Yirga (2008). Supplementation with concentrate mix to Hararghe highland sheep fed a basal diet of urea-treated maize stover: Effect on feed utilization, live weight change and carcass characteristics. An MSc Thesis Presented to School of Graduate Studies of Haramaya University. Pp. $32-48$

Humphreys, L.R. (1991).Tropical pasture utilization. Cambridge University, Great Britain. Pp. 206.

Kariuki, J. N. (1998). The potential of improving Napier grass under smallholder dairy farmers' conditions in Kenya. PhD Thesis, Wageningen Agricultural University, The Netherlands.

Kassahun Awgeichew., Yibrah Yacob and Fietcher, I.,(1989). Productive of pure breed Adal goats in Ethiopia.Pp.519523. In: Wilson, R.T. and Azeb Melaku (ed.). Proceedings of a Conference at Bamanda, Cameroon 1-25 January, African small Ruminant Research and Development. 4(5): 356-358.

Kirton, A.H., Bennet, L.G., Dobbie, L.J., Mercer, K.G., Duganzich, M.G. (1995). Effect of sire breed, sex and growth path on carcass composition of cross-breed lambs. Journal of Agricultural Research 38:105-114.

Liu, Jianxin., Zhang Yuan and Zhao Huo (1998). Effect of supplementation of mustard seed cake for Huzhou lambs offered untreated or ammoniated rice straw basal diet. Zhejiang University, Meng Qingxiang. China Agricultural University.

Mahgoub G., El Hag and Omer I. Kurdi (1984). Prospects for efficient utilization of agro-industrial byproducts and crop residues for ruminant feeding in the Sudan, with emphasis on quantification, nutritional composition, constraints and research results In: Proceedings of FAO/ILCA Expert consultation 5-9 March, 1984. Addis Ababa, Ethiopia.

Matiwos Solomon, Solomon Melaku and Adugna Tolera, 2008. Supplementation of cottonseed meal on feed intake, digestibility, live weight and carcass parameters of Sidama goats. Livestock Science 119: 137-144.

Mbaye, N.D. and Sall, C.H. (1982).La problematique de l'elevage en Afrique de l'ouest; l'alimentation du betail.LNERV, Dakar.

Merck, C., (2008). The Merck Veterinary Manual-Nutritional Requirements. Copy right Merial Limited, 76 Inc., Whitehouse Station, USA. 


\section{Tesfaye and Mengistu}

Mesfin Tadesse, (2007). The influence of age and feeding regime on the carcass trait of Arsi-Bale goats. Jimma University and Ambo College. Livestock Research for Rural Development 19(4).

Olorunju, P.E., Ntare, B.R., Babalo, O.A. and Alabi, O. (1996). In: Proceeding. Workshop on Nationally Coordinated Groundnut Research Project, 25-29 September, 1995, Zaria, Nigeria, Pp.47.

Osuji, P.O., Fernandez-Rivera, S. and Odenyo, A. (1995). Improving fiber utilization and protein supply in animals fed poor quality roughages: ILRI nutrition research plans. In: Rumen ecology research planning. Proceedings of the Workshop, ILRI, Addis Ababa, Ethiopia. ILRI, Nairobi, Kenya. Wallace R.J. and Lahlou Kassi, A. (eds.). (1995). pp. 1-22.

SAS (Statistical Analysis System) (2004).Statistical Analysis System. Institute Inc., Cary, NC, USA.

Shoo, R.A. (1986). A comparative study of roughage utilization and growth performance between sheep and goats supplemented with different levels of Leucaenaleucocephala. M.Sc Thesis, Sokoine University of Agriculture, Morogoro, Tanzania.
Sci. Technol. Arts Res. J., Jan-March 2014, 3(1): 57-63

Simret Betsha and Solomon Melaku. (2009). Supplementations of Hyparrheniarufa-dominated hay with groundnut cake- wheat bran mix: effects on feed intake, digestibility and nitrogen balance of Somali goats. Tropical Animal Health Production Springer Science 41: 927-933.

Titi, H.H., Tabbaa, M.J., Amasheh, M.G., Barakeh, F. and Daqamseh, B. (2000). Comparative performance of Awassi lambs and Black goat kids on different crude protein levels in Jordan. Small Ruminant Research 37: 131-135.

Vanes, A.J.H., (1979). Evaluation of Feeds Overall Application.pp.15-24. In: Pigden, W.J., Balch, C.C. and N. Graham (eds.). Standardization of Analytical Methodology for Feeds.Ottama, Canada.

Van Soest, P.J. and Robertson, J.B. (1985). Analysis of forage and fibrous feeds: a laboratory manual for animal sciences 613. Cornell University Ithaca, New York, USA .Pp. 202.

Wambui, C.C., Abdulrazak, S.A. andNoordin, Q. (2006). The effect of supplementing urea treated maize stover with tithonia, calliandra and sesbania to growing goats. Livestock Research for Rural Development 18(5). 